\title{
PERLINDUNGAN HUKUM BAGI PEMEGANG POLIS ASURANSI TERHADAP PENCABUTAN IZIN USAHA ASURANSI
}

\author{
Oleh: \\ Ahmad Zainudin \\ Magister Kenotariatan, Fakultas Hukum Universitas Surabaya \\ cazainudin@yahoo.com
}

\begin{abstract}
Abstrak-Penelitian hukum terhadap perlindungan hukum bagi pemegang polis terhadap pencabutan izin usaha asuransi perlu di lakukan secara serius sebagai suatu langkah pemenuhan atas hak-hak dari pemegang polis yang merupakan dampak dari pencabutan izin usaha asuransi yang dilakukan oleh menteri keuangan berdasarkan pasal 18 Undang-Undang No. 20 Tahun 1992 tentang Usaha Perasuransian. Oleh karena itu untuk memberikan perlindungan hukum bagi pemegang polis maka berdasarkan pasal 20 ayat (2) Undang-Undang Nomor 20 Tahun 1992 tentang Usaha Perasuransian. dimana hak pemegang polis tersebut harus didahukukan pembayaranya untuk itu maka harus dilakukan likuidasi untuk memenuhi hak-hak pemegang polis langkah hukum yang dilakukan adalah melakukan pembubaran pada perusahaan asuransi tersebut yang kemudian dilanjutkan dengan likuidasi yang dilakukan likuidator untuk melakukan pencatatan dan pemberesan harta kekayaan perusahaan berdasarkan pasal 149 ayat (1) Undang-Undang No. 40 Tahun 2007 tentang Perseroan Terbatas. Setelah dilakukan pencatatan dan pemberesan maka likuidator menggumumkan rencana pembagian harta kekayaan perusahaan berdasarkan pasal 149 ayat (1) Undang-Undang No. 40 Tahun 2007 tentang Perseroan Terbatas kepada pemegang polis. Pemegang polis mendapatkan pilihan pembayaran dengan adanya likuidasi ini, setuju dengan rencana pembagian kekayaan perusahaan tersebut dan menunggu pembayaran dari likuidator apabila tidak setuju pemegang polis dapat melakukan keberatan kepada likuidator berdasarkan pasal 149 ayat (3) Undang-Undang Nomor 40 Tahun 2007 tentang Perseroan terbatas jika keberatan tersebut ditolak maka pemegang polis dapat melakukan gugatan kepada likuidator sebagaimana telah diamanatkan oleh pasal 149 ayat (4) Undang-Undang Nomor 40 Tahun 2007 tentang Perseroan terbatas.
\end{abstract}

\section{Kata kunci: perlindungan hukum, pencabutan izin, pembubaran, likuidasi, pemenuhan hak,} kepastian hukum.

Abstract -legal research on the law protection for policyholders of insurance business license revocation needs to be in to do seriously as a step in the fulfillment of the rights of policyholders which is the impact of the Insurance Business license revocation by Minister of finance under article 18 Act No. 20 of 1992 about insurance business. Therefore to provide legal protection for policyholders then under article 20, paragraph (2) of Act No. 20 of 1992 about Insurance Business where rights holder of the policy should be precedence payment for it then to do the liquidation to meet policyholders 'rights legal step does is make the dissolution on the insurance companies that then proceed with the liquidation the liquidator to do done recording and settlement property company under section 149 subsection (1) of Act No. 40 of 2007 about limited liability company. After recording and settlement the liquidator declare corporate wealth distribution plan under section 149 subsection (1) of law No. 40 year 2007 on limited liability companies to policyholders. Policyholders get payment options with the existence of this liquidation, agreed with the company's wealth division plans and waiting for the 
payment of the liquidator if the policyholder does not agree may make an objection to the liquidator under section 149 subsection (3) of law No. 40 year 2007 on limited liability company if such objection is rejected then the policyholder can claim to the liquidator as mandated by article 149, paragraph (4) of law No. 40 year 2007 on limited liability company.

Keywords: law protection, revocation, dissolution, liquidation, fulfillment, legal certainty.

\section{A. PENDAHULUAN}

Era globalisasi dan perdagangan bebas yang selama ini selalu didengung-dengungkan oleh negara-negara maju tampaknya menuntut banyak perbaikan dari segala segi kehidupan bangsa dan negara, terutama bagi negara-negara berkembang seperti Indonesia. Situasi dunia politik dan ekonomi bangsa ini yang masih belum stabil masih menjadi kendala utama diterapkannya cita-cita tersebut. Oleh karena itu Pemerintah sebagai salah satu unsur penting harus memberikan perlindungan kepada masyarakatnya dengan asuransi sebagai contoh ketika indonesia meluncurkan satelit palapa B2 yang gagal masuk orbit karena kegagalan tersebut maka Indonesia mengklaim dan mendapat ganti kerugian dari perusahaan asuransi tersebut. Dalam bukunya Abdulkadir Muhammad, mengatakan asuransi merupakan: “...Verzekeraar dan Verzekerde yang diterjemahkan Verzekeraar dengan penanggung yaitu pihak yang menanggung resiko, sementara Verzekerde yaitu pihak yang mengalihkan resiko atas kekayaan atau jiwanya dengan penanggung."

Usaha Perasuransian merupakan satu mata rantai dalam perkembangan kegiatan perekonomian serta dianggap cukup penting dan oleh karenanya Negara Indonesia merasa perlu untuk mendirikan satu perusahaan asuransi yang mampu memenuhi kebutuhan asuransi. Keadaan seperti itulah yang yang kemudian mendatangkan rasa tidak aman karena dapat menimbulkan resiko. Pengertian usaha Perasuransian terdapat dalam Pasal 2 huruf (a) Undang-Undang No.2 Tahun 1992 tentang Usaha Perasuransian yaitu:

Usaha asuransi adalah usaha jasa keuangan yang dengan menghimpun dana masyarakat melalui pengumpulan premi asuransi memberikan perlindungan hukum kepada anggota masyarakat pemakai jasa asuransi terhadap kemungkinan timbulnya kerugian karena suatu peristiwa yang tidak pasti atau terhadap hidup atau meninggalnya seseorang.

Demikian juga kasus pada PT. Asuransi Syariah Mubarakah termasuk salah satu industri Asuransi Jiwa yang berbasis syariah. Perusahaan asuransi ini didirikan pada tanggal 18 oktober 1993 dengan nama PT. Asuransi Jiwa Mubarakah dengan menggunakan sistem operasi konvensional

\footnotetext{
${ }^{1}$ Abdulkadir Muhammad, Hukum Asuransi, Citra Aditya Bakti, 2011, hlm. 7.
} 
berdasarkan surat Keputusan Menteri Keuangan RI. No. 579/KMK.017/1997 yang diperoleh tanggal 13 november 1997 sebagai izin usaha dan operasinya. Dan kemudian terjadi peralihan sistem operasi dari konvensional menjadi syariah penuh dilaksanakan pada tanggal 3 mei 2001. Dengan perubahan sistem operasi ini, PT.Syariah Mubarakah tercatat sebagai perusahaan swasta nasional yang beroperasi secara syariah penuh di Indonesia.

Tapi dalam prosesnya perusahaan asuransi ini mengalami beberapa masalah dengan syarat berdirinya perusahaan asuransi, sampai pada akhirnya dilakukan pencabutan izin usaha oleh menteri keuangan pada tanggal 28 desember 2012 berdasarkan Keputusan Menteri Keuangan KEP 779/KM10/2012. Hal ini dilakukan Menteri Keuangan guna menghindari kerugian yang lebih besar lagi.

Dengan adanya pencabutan izin usaha asuransi, perusahaan asuransi tersebut tidak dapat lagi melaksanakan kegiatan usahanya di bidang perasuransian. Sebagai sebuah badan usaha yang berbadan hukum, perusahaan asuransi juga berkewajiban untuk melakukan likuidasi atau penyelesaian segala kewajiban sehubungan dengan pembubaran badan hukum. Hal ini tidak dilaksanakan oleh likuidator PT. Asuransi Syariah Mubarakah sehingga hak-hak dari para nasabah PT. Asuransi Syariah Mubarakah tersebut harus terpenuhi. Kondisi yang merugikan para nasabah tersebut perlu disikapi dengan serius agar muncul perlindungan hukum bagi para tertanggung yang klaim asuransinya tidak dibayar oleh PT. Asuransi Syariah Mubarakah setelah adanya pencabutan izin asuransi.

\section{B. METODO PENELITIAN}

a. Tipe Penelitian

Penelitian ini merupakan penelitian hukum normatif (yuridis normatif), merupakan penelitian kepustakaan, yaitu penelitian yang didasarkan pada peraturan perundang-undangan yang berlaku dan literatur-literatur lainnya yang berkaitan dengan pokok bahasan sebagai bahan pendukung.

b. Pendekatan

Pendekatan masalah dalam penelitian ini dilakukan dengan menggunakan pendekatan secara perundang-undangan (statue approach) dan pendekatan konsep (conceptual approach). Pendekatan secara perundang-undangan (statue approach) adalah penelitian yang pendekatan utamanya melalui peraturan perundang-undangan yang berlaku. Sedangkan pendekatan konsep (conceptual approach) adalah pendekatan yang diperoleh melalui literatur dan bahan bacaan lainya sebagai teori pendukung dari pembahasan tersebut untuk memperlancar penelitian ini.

c. Bahan Hukum 
Bahan hukum untuk penelitian ini terdiri sebagai berikut:

1. Bahan Hukum Primer, yakni berupa peraturan perundang-undangan yaitu Undang- Undang Nomor 2 Tahun 1992 tentang Usaha Perasuransian dan peraturan perundang-undangan lain yang terkait.

2. Bahan Hukum Sekunder, yakni berupa buku-buku hukum, karya tulis ilmiah, ataupun bukubuku yang bersifat tidak mengikat namun menerangkan tentang bahan hukum primer yang terkait dengan penelitian ini, seperti majalah, surat kabar, dan sumber dari beberapa situs internet yang berkaitan dengan permasalahan di atas.

\section{d. Langkah Penelitian Hukum}

Langkah yang dapat dilakukan dalam menjawab permasalahan yang terjadi adalah mengidentifikasi masalah kemudian menggunakan penalaran yang bersifat deduktif yaitu dari umum ke khusus yang digunakan untuk menjawab permasalahan tersebut. Setelah permasalahan tersebut telah terjawab maka saya menarik kesimpulan dari jawaban atas permasalahan tersebut.

\section{HASIL DAN PEMBAHASAN}

\section{a. Kronologi Kasus}

Perusahaan asuransi sebagai lembaga keuangan harus memperhatikan mengenai ketentuan mengenai kesehatan keuangan Perusahaan Perasuransian, agar Perusahaan Perasuransian di Indonesia senantiasa dapat memenuhi kewajiban-kewajibannya kepada pemegang polis. Hal ini terjadi pada PT.Asuransi Syariah Mubarakah yang mengalami pencabutan izin berdasarkan Keputusan Menteri Keuangan Republik Indonesia Nomor:KEP-779/KM.10/2012 tentang Pencabutan Izin Usaha di bidang Asuransi Jiwa berdasarkan prinsip syariah kepada PT. Asuransi Syariah Mubarakah tanggal 28 desember 2012, untuk melindungi kepentingan pemodal, masyarakat dan untuk mencegah kerugian pemegang polis yang akan timbul kemudian sebagai akibat pelanggaran atas peraturan perundangundangan di bidang Peruasuransian.

Dalam proses menjalankan usaha asuransi PT. Asuransi Syariah Mubarakah, Perusahaan Asuransi wajib menjaga tingkat solvabilitas yang diatur dalam Pasal 11 ayat (1) dan ayat (2) UndangUndang Nomor 2 Tahun 1992 tentang Usaha Perasuransian.

Kemudian berdasarkan hal tersebut melalui Keputusan Menteri Keuangan Nomor: 424/KMK.06/2003 tentang Kesehatan Keuangan Perusahaan Asuransi dan Perusahaan Reasuransi harus memenuhi tingakat solvabilitas yang diatur dalam Pasal 2 ayat (1) yaitu:'Perusahaan Asuransi 
dan Perusahaan Reasuransi setiap saat wajib memenuhi tingkat solvabilitas paling sedikit $120 \%$ (seratus dua puluh per seratus) dari resiko kerugian yang mungkin timbul sebagai akibat dari deviasi dalam pengelolaan kekayaan dan kewajiban."

Dengan adanya Keputusan Menteri Keuangan tersebut PT. Asuransi Syariah Mubarakah tidak dapat memenuhi ketentuan mengenai tingkat solvabilitas dari Perusahaan Asuransi karena adanya pelanggaran terhadap ketentuan perundang-undangan terserbut maka Menteri Keuangan berdasarkan Pasal 17 ayat (2) Undang-Undang Nomor. 2 Tahun 1992 tentang Usaha Perasuransian dapat melakukan tindakan berupa pemberian peringatan, pembatasan kegiatan usaha, atau pencabutan izin usaha.

Pelanggaran yang terjadi pada PT. Asuransi Syariah Mubarakah berujung pada pemberian Sanksi Peringatan pertama dengan Surat Nomor: S-716/MK.10/2010 tanggal 8 juli 2010. Penyebab Sanksi ini berdasarkan Laporan Triwulan I/2010, rasio pencapaian solvabilitas $61 \%$ dan rasio perimbangan Investasi $82 \%$.

Sanksi Peringatan kedua diberikan dengan Surat Nomor: S-1034/MK.10/2010 tanggal 29 oktober 2010. Penyebab Sanksi ini dikarenakan PT. Asuransi Syariah Mubarakah belum mengatasi penyebab dikarenakan Sanksi Peringatan Pertama.

Sanksi Peringatan Ketiga diberikan dengan Surat Nomor: S-1116/MK.10/2010 tanggal 10 desember 2010. Penyebab Sanksi ini dikarenakan PT. Asuransi Syariah Mubarakah belum mengatasi penyebab dikarenakan Sanksi Peringatan Kedua.

Karena dari tiga kali pemberian Peringatan oleh Menteri Keuangan tidak segera ditindak lanjuti oleh PT. Asuransi Syariah Mubarakah maka Menteri Keuangan memberikan Sanksi Pembatasan Kegiatan Usaha dengan Surat Nomor:S-240/MK.10/2011 tanggal 21 maret 2011. Penyebab Sanksi ini dikarenakan PT. Asuransi Syariah Mubarakah belum mengatasi penyebab dikarenakan Sanksi Peringatan ketiga.

Pemberian sanksi berupa Pembatasan Usaha asuransi ini dilakukan agar Perusahaan asuransi tersebut menyusun Rencana Penyehatan Keuangan dengan segera hal ini diatur dalam Pasal 42 ayat (1) Peraturan Pemerintah Nomor 73 Tahun 1992 tentang Penyelenggaran Usaha Perasuransian yaitu:"sanksi pembatasan kegiatan usaha sebagaimana dimaksud dalam Pasal 41 ayat (3) berlaku sejak tanggal di tetapkan untuk jangka waktu paling lama 12 (dua belas) bulan."

Dengan adanya Pembatasan Kegiatan Usaha maka Menteri memberikan waktu kepada PT. Asuransi Syariah Mubarakah untuk menyusun Rencana Penyehatan Keuangan sesuai dengan ketentuan Pasal 17 ayat (3) Undang-Undang Nomor 2 Tahun 1992 tentang Usaha Perasuransian yang menyatakan 
bahwa:"sebelum melakukan pencabutan izin usaha, Menteri dapat memerintahkan perusahaan yang bersangkutan untuk menyusun rencana dalam rangka mengatasi penyebab dari pembatasan kegiatan usahanya."

Dalam hal Pemberian Sanksi tersebut Menteri Keuangan tetap mengawasi kegiatan dari Perusahaan Asuransi tersebut dengan melalui Surat Nomor:S-6417/BL/2010 terkait perbaikan rencana Penyehatan Keuangan PT. Asuransi Syariah Mubarakah agar di buat lebih mendalam dan Surat Nomor:S-7417/BL/2010 yang meminta pada PT. Asuransi Syariah Mubarakah untuk memperbaiki Rencana Penyehatan Keuangan sehingga dapat memberikan gambaran yang jelas mengenai keadaan Perusahaan Asuransi. Penyampaian laporan keuangan kepada Menteri Keuangan harus dilakukan secara berkala guna penilaian yang lebih baik dari Menteri Keuangan yang telah diatur dalam Pasal 42 ayat (2) Peraturan Pemerintah Nomor 73 Tahun 1992 tentang Penyelenggaran Usaha Perasuransian yaitu:"dalam hal Menteri menilai diperlukan adanya suatu rencana dari sanksi pembatasan kegiatan usaha, pada saat penetapan pembatasan kegiatan usaha Menteri dapat memerintahkan penyusunan rencana kerja yang harus disampaikan kepada Menteri dalam jangka waktu paling lama 3 (tiga) bulan.”

Selama dikenakan sanksi tersebut Menteri keuangan tetap memberikan pembinaan dengan melakukan pertemuan-pertemuan dengan PT. Asuransi Syariah Mubarakah dalam membahas upaya Penyehatan Keuangan dengan membantu mencari investor yang dapat memberikan modal untuk kelangsungan PT. Asuransi Syariah Mubarakah yang dapat membantu kelangsungan perusahaan tersebut tetapi perusahaan tersebut dalam jangka waktu yang ditentukan masih tidak dapat melakukan penyehatan terhadap perusahaan.

Usaha yang dilakukan oleh PT. Asuransi Syariah Mubarakah dalam rangka Penyehatan Keuangan Perusahaan telah ditempuh langkah-langkah yang cukup, baik dalam bentuk surat menyurat maupun pertemuan, termasuk pemberian kesempatan untuk dilakukan akuisisi. Akan tetapi PT. Asuransi Syariah Mubarakah tetap tidak dapat mengatasi penyebab dikarenakan sanksi, sehingga berdasarkan Pasal 18 Undang-Undang Nomor 2 Tahun 1992 tentang Usaha Perasuransian yaitu:

Dalam hal tindakan untuk memenuhi rencana sebagaimana dimaksud dalam pasal 17 ayat (3) telah dilaksanakan dan apabila dari pelaksanaan tersebut dapat disimpulkan bahwa perusahaan yang bersangkutan tidak mampu atau tidak bersedia menghilangkan hal-hal yang menyebabkan pembatasan termaksud, maka Menteri mencabut izin usaha perusahaan.

Ditambah dengan Pasal 42 ayat (4) Peraturan Pemerintah Nomor 73 Tahun 1992 tentang Penyelenggaran Usaha Perasuransian sebagai berikut: 
Dalam hal Perusahaan Perasuransian tidak dapat mengatasi penyebab dari sanksi pembatasan kegiatan usaha dalam jangka waktu sebagaimana dimaksud dalam ayat (1), atau dari pelaksanaan rencana keja sebagaimana dimaksud dalam ayat (2) dalam jangka waktu sampai berakhirnya sanksi sebagaimana dimaksud dalam ayat (1) disimpulkan bahwa perusahaan tidak mampu atau tidak bersedia mengatasi penyebab dari sanksi termaksud, Menteri mencabut izin usaha Perusahaan Tersebut.

Maka pada tanggal 28 desember 2012 Menteri Keuangan menerbitkan surat Keputusan Menteri Keuangan Republik Indonesia Nomor: KEP-779/KM.10/2012 tentang pencabutan Izin Usaha di Bidang Asuransi Jiwa berdasarkan prinsip Syariah atas PT. Asuransi Syariah Mubarakah.

\section{b. Analisis}

Pecabutan izin PT. Asuransi Syariah Mubarakah ini menimbulkan kewajiban-kewajiban dari PT. Asuransi Syariah Mubarakah, untuk memenuhi kewajiban tersebut kepada pemegang saham, hutang kepada pihak lain, pembayaran upah pegawai sampai pembayaran klaim asuransi dari pemegang polis yang jumlahnya terdiri dari ribuan individu/perseorangan dan badan hukum baik swasta ataupun Badan Usaha Milik Negara yang saat ini mencapai 574.603 (lima ratus tujuh puluh empat ribu enam ratus tiga) peserta porto polis dan 4.130 (empat ribu seratus tiga puluh) peserta polis inforce.

Lora yang merupakan peserta asuransi dari PT. Asuransi Syariah Mubarakah sendiri merasa dirugikan dengan adanya pencabutan izin tersebut karena pada saat Lora mengajukan klaim tetapi tidak dapat menerima klaim karena adanya pencabutan izin tersebut kondisi ini harus segera disikapi dengan serius untuk memberikan perlindungan hukum terhadap perserta asuransi lain yang mengalami keadaan yang sama seperti Lora.

Pemegang polis dalam hal ini adalah para pihak yang melakukan perjanjian asuransi dan telah memenuhi syarat-syarat sahnya asuransi yang telah dijelaskan pada bab sebelumnya, para pihak yang melakukan perjanjian asuransi tersebut akan mendapatkan polis yang sebagai bukti adanya perjanjian asuransi.

Mengingat bahwa ada dua sifat piutang yaitu preferen dan konkuren dimana kreditor preferen adalah mereka yang mempunyai piutang yang dijamin dengan hak gadai, hak hipotik dan sebagainya yang didahulukan pembayaranya.

Dengan kata lain kedudukan pemegang polis asuransi tidak termasuk dalam piutang yang diistimewakan atau dapat dikatakan bahwa pemegang polis sebagai kreditur konkuren. Dalam bukunya Lilik Mulyadi menjelaskan pengertian Kreditor konkuren sebagai berikut:'Kreditor yang memiliki hak 
pari passu prorate parte, para Kreditor mendapatkan penlunasan bersama-sama tanpa hak didahulukan, dihitung besarnya piutang berdasarkan besarnya piutang masing-masing terhadap piutang secara keseluruhan dari seluruh kekayaan Debitor."

Berdasarkan penjelasan diatas maka penulis berpendapat bahwa dengan adanya asas hukum yang digunakan dalam hukum Indonesia salah satunya adalah "lex specialis derograt legi generale" yaitu peraturan yang bersifat khusus dapat mengalahkan peraturan yang bersifat umum. Jika melihat dari pengertian tersebut maka aturan yang bersifat khusus yang seharusnya diterapkan yaitu UndangUndang Nomor 2 Tahun 1992 tentang Usaha Perasuransian sehingga sesuai aturan tersebut dalam menentukan hak polis telah diatur dalam Pasal 20 ayat (2) yaitu:"'hak pemegang polis atas pembagian harta kekayaan Perusahaan Asuransi Kerugian atau Perusahaan Asuransi Jiwa yang dilikuidasi merupakan hak utama." Berdasarkan asas hukum tersebut apabila terjadi pertentangan antara peraturan hukum yang bersifat umum dan khusus maka peraturan yang bersifat khusus yang berlaku.

Dengan demikian jika dikaitkan dengan hak istimewa yang dimiliki pemegang polis maka dalam Pasal 1134 Kitab Undang-Undang Hukum Perdata mengatur bahwa:

Hak istimewa ialah suatu hak yang oleh undang-undang diberikan kepada seorang berpiutang sehingga tingkatnya lebih tinggi daripada orang berpiutang lainya, semata-mata berdasarkan sifat utangnya. Gadai dan hipotik adalah lebih tinggi daripada hak istimewa, kecuali dalam hal-hal dimana oleh undang-undang ditentukan sebaliknya.

Oleh karena itu sesuai dengan Pasal 20 Undang-Undang Nomor 2 Tahun 1992 tentang Usaha Perasuransian maka kedudukan pemegang polis diutamakan dibandingkan dengan kreditur yang lainnya.

Untuk menyelsaikan pembayaran terhadap pemegang polis PT. Asuransi Syariah Mubarakah yang tidak dapat lagi melakukan usaha dibidang asuransi karena pencabutan izin usaha tersebut harus melakukan likuidasi sebagai bentuk pertanggungjawaban terhadap penyelsaian pembayaran klaim asuransi dan segala hutang perusahaan yang harus dibayar.

Sesuai dengan adanya pencabutan izin usaha PT. Asuransi Syariah Mubarakah tersebut maka sesuai dengan Pasal 20 Undang-Undang Nomor 2 Tahun 1992 tentang Usaha perasuransian maka perurahaan harus melakukan likuidasi hal ini dilakukan sebagai perlindungan terhadap harta kekayaan perusahaan tersebut yang diatur dalam Pasal 142 ayat (1) huruf f Undang-Undang Nomor 40 tahun 2007 tentang Perseroan Terbatas, perseroan bubar karena:"Karena dicabutnya izin usaha Perseroan

\footnotetext{
${ }^{2}$ Lilik Mulyadi, Perkara Kepailitan dan Penundaan Kewajiban Pembayaran Utang (PKPU) Teori dan

Praktik. PT. Alumni, 2010, Bandung, Hlm. 89
} 
sehingga mewajibkan Perseroan melakukan likuidasi sesuai dengan ketentuan peraturan perundangundangan."

Pada proses likuidasi ini PT. Asuransi Syariah Mubarakah harus segera menunjuk likuidator melalui Rapat Umum Pemegang Saham (RUPS) agar proses likuidasi ini dapat dengan cepat berjalan sehingga tidak merugikan pemegang polis. Penunjukan likuidator berdasarkan Pasal 142 ayat (3) Undang-Undang Nomor 40 Tahun 2007 tentang Perseroan terbatas hal ini berarti penunjukan likuidator dapat dilakukan sesuai dengan Pengadilan Niaga dan Rapat Umum Pemegang Saham tetapi dalam hal tidak menunjuk likuidator maka demi hukum direksi dari PT. Asuransi Syariah Mubarakah dapat bertindak sebagai likuidator terkait hal tersebut dalam bukunya Rudhi Prasetya menjelaskan sebagai berikut:"logika praktisnya, yang akan menjalankan pemberesan itu adalah pihak Direksi, karena Direksi yang paling mengetahui keadaan perseroan."3

Setelah adanya penunjukan likuidator yang diatur dalam Pasal 142 ayat(3) Undang-Undang Nomor 40 Tahun 2007 tentang Perseroan Terbatas maka likuidator dengan segera melakukan pemberesan harta dari perusahaan tersebut tetapi dalam melaksanakan kewajiban tersebut likuidator tidak dapat berbuat sewenang-wenang melainkan sudah diatur mengenai bagaimana cara dalam melakukan pemberesan harta kekayaan perusahaan tersebut. Kewajiban likuidator dalam pemberesan harta kekayaan yang diatur dalam Pasal 149 ayat (1) Undang-Undang Nomor 40 tahun 2007 tentang Perseroan Terbatas.

Dalam melakukan pemberesan harta, likuidator harus dengan teliti dalam melakukan pencatatan dan pengumpulan kekayaan dari PT. Asuransi Syariah Mubarakah sebagaimana telah ditentukan Pasal 149 ayat (1) Undang-Undang Nomor 40 Tahun 2007 tentang Perseroang Terbatas. Likuidator memiliki tugas jika ada harta yang berada dalam kekuasaan perusahaan dalam likuidasi, tetapi sebenarnya harta tersebut bukan atau belum menjadi milik perusahaan dalam likuidasi tersebut harus dikembalikan kepada pemiliknya. Setelah benar-benar semua adalah milik perusahaan maka likudator dapat melakukan penjualan harta kekayaan. Dengan demikian likuidator dalam melaksanakan kewajibanya harus menelusuri kalau ada pihak lain yang mungkin (dalam atau luar perseroan) yang mungkin dapat dimintakan pertanggungjawaban secara hukum, pertanggungjawaban mana jika terealisasi dapat menambah aset perseroan dalam likuidasi. ${ }^{4}$ Tapi dalam hal melakukan perbuatan hukum yang

\footnotetext{
${ }^{3}$ Rudhi Prasetya Teori dan Praktik Perseroan Terbatas. Sinar Grafika, 2011, hlm.167

${ }^{4}$ Munir Fuady, Perseroan Terbatas Paradigma Baru, Citra Aditya Bakti, 2003, Bandung, hlm.190 
berkaitan dengan PT. Asuransi Syariah Mubarkah likuidator harus menuliskan kata "dalam likuidasi" dibelakang nama perseroan.

Berdasarkan hasil penjualan tersebut piutang-piutang terhadap kreditur harus dibayarkan, tapi pembayaran yang dilakukan berdasarkan uraian diatas pemegang polis pembayaranya harus diutamakan daripada kreditor yang lain, yang diatur dalam Pasal 20 Undang-Undang Nomor 2 Tahun 1992 tentang Usaha Perasuransian. Jadi dalam hal ini pembayaran kepada pemegang polis didahulukan yang kemudian baru dibayarkan kepada kreditor yang lain.

Oleh karena itu, perlindungan hukum bagi Lora selaku pemegang polis yang diterbikan oleh PT. Asuransi Syariah Mubarakah setelah adanya pencabutan izin oleh Menteri Keuangan adalah memperoleh pemenuhan atas hak-haknya. Pemenuhan tersebut dilakukan oleh likuidator sebagaimana ditentukan dalam Pasal 149 Undang-Undang Nomor 40 Tahun 2007 tentang Perseroan Terbatas, bahwa kewajiban likuidator adalah melakukan pembayaran kepada kreditor hal tersebut dapat dilakukan setelah adanya pencatatan dan pemberesan oleh likuidator.

\section{KESIMPULAN DAN SARAN TINDAK LANJUT}

\section{a. Kesimpulan}

Berdasarkan uraian dari bab-bab sebelumnya maka dapat diambil kesimpulan sebagai berikut:

a. Bahwa Lora yang merupakan pemegang polis PT. Asuransi Syariah Mubarakah melakukan perjanjian pertanggungan dengan produk asuransi wadiah haji sampai pada saat akan mengajukan klaim ternyata izin usaha perusaahaan tersebut telah dicabut sesuai dengan Pasal 18 UndangUndang Nomor 2 Tahun 1992 tentang Usaha Perasuransian kondisi ini sangat merugikan kepentingan dari tertanggung sehingga harus disikapi dengan serius.

b. Bahwa pencabutan izin yang dilakukan oleh Menteri Keuangan berdasarkan Keputusan Menteri Keuangan Republik Indonesia Nomor:KEP-779/KM.10/2012 hal ini berawal dari ketidakmampuan PT. Asuransi Syariah Mubarakah dalam melakukan penyehatan keuangan, berdasarkan hal tersebut maka perusahaan tersebut sesuai dengan Undang-Undang Nomor 40 Tahun 2007 tentang Perseroan Terbatas harus melakukan likuidasi guna melakukan pembayaran terhadap pemegang polis sebagai bentuk perlindungan hukum.

c. Bahwa untuk memperoleh perlindungan hukum atas pemenuhan hak bagi Lora selaku pemegang polis asuransi dengan adanya likuidasi adalah memperoleh pembayaran oleh likuidator setelah dilakukan pencatatan dan pemberesan harta kekayaan PT. Asuransi Syariah Mubarakah. Apabila 
Lora merasa keberatan terhadap rencana pembagian hasil likuidasi berdasarkan Pasal 149 ayat (3) Undang-Undang Nomor 40 Tahun 2007 tentang Perseroan Terbatas Lora dapat mengajukan keberatan pada likuidator.

\section{b. Saran}

Hendaknya likuidator segera mengumumkan rencana pembagian hasil kekayaan perusahaan. Apabila Lora merasa keberatan, maka sesuai pasal 149 ayat (3) Undang-Undang Nomor 40 Tahun 2007 tentang Perseroan Terbatas Lora dapat mengajukan keberatan pada likuidator. Kemudian jika keberatan yang diajukan tersebut ditolak, Lora dapat mengajukan gugatan pada Pengadilan Negeri tempat kedudukan PT. Asuransi Syariah Mubarakah berdasarkan Pasal 149 ayat (4) Undang-Undang Nomor 40 Tahun 2007 tentang Perseroan Terbatas untuk memperoleh perlindungan hukum atas pemenuhan hak-haknya.

\section{DAFTAR PUSTAKA}

\section{Buku}

Ali, Zainuddin. Hukum Asuransi Syariah. Sinar Grafika. Jakarta. 2008.

Fuady, Munir. Perseroan Terbatas Paradigma Baru. Citra Aditya Bakti. Bandung. 2003.

Ganie, A.Junaedy. Hukum Asuransi Indonesia. Sinar Grafika. Jakarta. 2013.

Hartono. Sri Rejeki. Hukum Asuransi. Sinar Grafika. Jakarta. 2001.

Muhammad, Abdulkadir. Hukum Asuransi. PT. Citra Aditya Bakti. Bandung. 2011.

Mulyadi, Lilik. Perkara Kepailitan dan Penundaan Kewajiban Pembayaran Utang (PKPU) Teori dan Praktik. PT. Alumni. Bandung. 2010.

Prasetya, Rudhi. Teori dan Praktik Perseroan Terbatas. Sinar Grafika. Bandung. 2011.

\section{Karya Ilmiah Hukum}

Fikri, M. Agung Ali. Pengaruh Premi, Klaim, Hasil Investasi dan Underwritting Terhadap Laba Asuransi Jiwa (Studi Kasus PT. Asurasnsi Syariah Mubarakah). Departemen Manajemen fakultas Ekonomi dan Manajemen Instutut Pertanian Bogor. Bogor. 2009.

\section{Internet}

Lubis, Sukowati. Seminar Nasional "Kebijakan dan Prospek Asuransi serta Penyelesaian Sengketa Klaim”, Universitas Surabaya. Surabaya. 2013. 